\title{
Multi-class Models for Assessing the Financial Condition of Manufacturing Enterprises \\ Sebastian Klaudiusz Tomczak
}

ABSTRACT

\begin{abstract}
Since 2007, the operating conditions of companies have changed significantly and can be described as more unpredictable. Insolvency of one company may, by the domino effect, have negative impacts on other operators. In extreme cases, these impacts can lead to their bankruptcy. Therefore, it is important to constantly monitor both the financial condition of a company and the financial condition of its business partners. In order to evaluate the financial standing of a company different types of methods can be employed. The aim of the paper was to build two models that specify more than two states of financial standing of manufacturing businesses. The use of the models enables recognition of the deteriorating financial condition of manufacturing companies a few years before insolvency is declared. The traditional discriminant model and Bayesian model were constructed. Cluster analysis was used to select classes of financial standing of the analyzed companies. The models were tested on two sets of samples. A small sample consisted of $224(112+112)$ companies and a large sample consisted of more than 10,600 companies. The results showed that the traditional discriminant model performs better than the Bayesian model for classifying companies.
\end{abstract}

KEY WORDS: financial standing, integrated models, manufacturing sector, cluster analysis.

JEL Classification: G01, G33, L60.

Wrockaw University of Science and Technology, Poland

\section{Introduction and Overview}

Nowadays, it is compulsory to monitor a company's financial condition as well as the financial condition of its business partners because of the risk of company insolvency. Businesses are interconnected. Loss of ability to repay the obligations of one of the business partners may entail a wave of bankruptcy, the domino effect (Cheung \& Levy, 1998). Specialists claim that $27 \%$ of business failure is caused by the bankruptcy of other undertakings (Jackson \& Wood, 2013).

There are numerous methods for calculating the financial standing of enterprises. One of them is called a

Correspondence concerning this article should be addressed to: Sebastian Klaudiusz Tomczak, Wrocław University of Science and Technology, Poland. E-mail: sebastian.tomczak@ pwr.edu.pl ratio analysis. Beaver (1966) was the first who verified the empirically possibility of using financial ratios to recognize the threat of bankruptcy of companies. He analyzed 30 ratios and six ratios considered as useful for assessing bankruptcy prediction of a company. He estimated his model based on 158 US companies. The results shown that his model correctly classified companies with the percentage of 83,5 . However, using this analysis researchers cannot evaluate a company as a whole, but can only assess groups of ratios. In turn, Altman (1968) was the first who applied a multidimensional discriminant analysis to assess financial situation of a company. He analyzed 22 ratios and only 5 of them presented in his synthetic model. The test sample consisted of 25 bankrupt companies as well as 66 still operating companies. The results of the test 
sample were at the level of $96 \%$ of correct recognition of bankrupt companies and 79\% correct recognition of still operating companies. Altman (1993), Altman and Hotchkiss (2006) tested his model based on 25, 33, $66,86,110$, and 120 companies. The models were also constructed outside of United States. Another wellknown discriminant models are the Springate (1978), the Taffler (1983). The first one was constructed for the Canadian market, and the second one for UK market. Springate selected 4 from 19 financial ratios to his model. He shown that the model has the accuracy rate of $92.5 \%$ based on the sample of 40 companies. In turn, Taffler analyzed over 80 carefully picked ratios and selected only 4 . The accuracy of Taffler model was at the level of $95.5 \%$ on the basis of 92 companies.

In Poland, after political transformation, many models have been constructed to examine the financial condition of a firm as well as to classify them as "those in good condition" and as " those in poor condition" presenting high risk of bankruptcy (healthy or not healthy). The most popular models are those of: Gajdka and Stos (1996a, 1996b, 2003) - models consist of 4-5 selected ratios from 20, sample of companies from 40 to 150 , accuracy oscillated between $82,5 \%$ $100 \%$, Hołda (2001), model consists of 5 selected ratios from 28, sample of 40 companies, accuracy was at 92.5\%, Appenzeller and Szarzec (2004) models consist of selected 5-6 ratios from 19, sample of 68 companies, accuracy oscillated between 85,29\%-88,23\%, Hamrol, Czajka, Piechocki (2004) model consists of 4 ratios from 31, sample of 100 companies, accuracy was at 96\%, Prusak (2005), models consist of 3-4 ratios from more than 30 ratios, sample of 78 companies, accuracy of the models oscillated between $93.51 \%-100 \%$, Mączyńska and Zawadzki (2006), models consist of 4-11 ratios from 45, sample of 80 companies, accuracy of the models oscillated between 85.2-96.9\%, Juszczyk and Balina (2014), models consist of 3 or 4 ratios from 42 ratios, sample of 120 companies, accuracy of the models oscillated between 77.5-92.5\%,

These are not the only works dealing with issues of the evaluation of the financial condition of enterprises. Especially, when it comes to use of the increased computer power and computing speed, several methods based on artificial intelligence and expert systems, e.i. neural networks have to be taken into consideration. They are more sophisticated, advanced methods. However, discriminant models are easier to implement, compare and evaluate. That is why they are more often verified when it comes to enterprises operating in Poland. More information about the types of methods, the authors of the methods and the development of methods can be found in: Altman and Saunders (1998), Bellovary, Giacomino, Akers (2007).

The usefulness of models has been verified by others researchers from all the world. They have carried out an analysis of the accuracy of existing models. Grice and Ingram (2001); Reisz, Perlich (2007); Wu Gaunt, Gray (2010); Lyandres, Zhdanov (2013); Altman, Iwanowicz-Drozdowska, Laitinen, Suvas (2017) tested the accuracy of models based on a larger sample. They investigated mostly the effectiveness of the Altman model over time on a sample of 979, 1,002 companies; 5,784 companies; 50,611 companies; 146,836 companies; 3191743 companies. In Poland, the verification of such models has been carried out by, among others for more than 100 companies in the sample: Juszczyk and Balina (2014) - 120 companies, Kisielińska (2016) - 110 companies, Tomczak, Radosiński (2017) - 10,600 companies; Altman, Iwanowicz-Drozdowska, Laitinen, Suvas (2017) - 86,497 companies.

Based on an analysis of the literature, the most effective models are built on the basis of 3 to 5 indicators (Tomczak, Radosiński, 2017) and in many cases, many of these indicators are repeated in the models, these are usually financial ones e.g. current ratio which is one of the most common indicator used in bankruptcy prediction models (Tomczak, 2014). Moreover, most of the models had significantly reduced overall accuracy in comparison to the accuracy presented by the authors of models. None of the models evaluated financial situation of companies with the accuracy at the level of $95 \%$. Therefore, so far, no single optimal bankruptcy prediction model has been established, for which a very high efficiency can be assured. In addition, the accuracy of models was verified based on a small research sample which did not sufficiently show the efficiency of a particular model. Furthermore, companies were not characterized by only two states healthy or not healthy. There are also intermediate states, such as questionable, satisfactory (Majewska \& Zdanowicz, 2006), or sufficient financial condition (Mączyńska, 1994). Finally, some models were not constructed for a specific sector, which may influence 
their accuracy. Therefore, the aim of the research is to develop two models: traditional discriminant model and Bayesian model to identify more than two states of financial standing of companies. The use of the models allows to predict the deteriorating financial situation of manufacturing companies several years before their bankruptcy. The models were tested on the basis of a large sample of approximately 11,000 enterprises.

\section{Methodology of Research}

The aim of the paper was to construct two models that specify more than two states of financial condition of manufacturing companies. The use of the models enables recognition of the declining financial standing of manufacturing businesses several years before insolvency is declared. The paper describes the process of constructing the two models, the traditional discriminant model and Bayesian model, consisting of many elements.

The financial reports of companies were downloaded from the EMIS database (EMIS stands for Emerging Markets Information Service, a Euromoney Institutional Investor Company, www. emis.com). In total, approximately 700 bankrupt businesses and over 10,000 companies remaining in operation were selected to the analysis. More details about the database of financial statements can be found in Tomczak, Radosińki (2017).

First, the models were constructed based on a learning (training) test sample of 200 companies. Half of them (100 companies) were companies that have gone bankrupt and/or were in liquidation. The other half (100 companies) were companies characterized by a relatively good financial condition (on the basis of ratio analysis). Second, the models were verified based on the test sample - 224 companies. Similar to the learning sample, half of them (112 companies) are companies that have gone bankrupt and/or are in liquidation. The other half (112 companies) were companies characterized by a relatively good financial condition (on the basis of ratio analysis). Third, the accuracy of the models was verified based on a validation sample - analysis of accuracy type I approximately 600 bankrupt companies and analysis of accuracy type II more than 10,000 still operating companies. Type I accuracy (EI) is the percentage of properly classified bankrupt companies, while type
II accuracy (EII) is the percentage of non-bankrupt enterprises correctly classified. It is worth pointing out that the enterprises remaining in the learning sample were excluded from the test and validation samples.

\section{Model}

First, the assumptions for the models - the defects of existing models, mentioned above, were indicated, and were eliminated by using the new models. Second, the learning sample for the models - the models were constructed based on a training sample of 200 companies. Half of them (100 companies) were companies that have gone bankrupt and/or were in liquidation. The other half (100 companies), were companies characterized by a relatively good financial condition (on the basis of ratio analysis). Third, the selection of financial ratios - the indicators most often used in discriminant models and financial analysis were analyzed. A total of 64 financial indicators used in bankruptcy prediction models and financial analysis were taking into consideration (see annex). Specified indicators were grouped into five areas of activity: liquidity, profitability, debt, turnover, and other. Next, the normal distribution of the values of selected ratios was tested using a normality Kolmogorov - Smirnov test. Those values that did not obtain a normal distribution, after the removal of outliers were rejected from further selection of indicators. Later, the predictive and discriminant abilities of indicators were checked. If the values of ratios decrease or increase in a minimum of three consecutive years before bankruptcy it means that the ratio is characterized by a predictive ability.

Together with predictive ability, indicators should be characterized by discriminant ability, having large differences in the values of ratios between enterprises in poor and good financial condition (Tomczak 2014). This was checked by using a Student's $t$ test for independent samples. At the end of the selection, the indicators that were highly correlated with each other were excluded from the analysis. Fourth, the estimation of the discriminant feature of the indicators - Wilk's Lambda coefficient was calculated. The selected financial ratios were inputted into the Statistica 13 software. The main goal in selecting variables to be included in a model was the choice of such a combination of variables, for which the 
rate was the lowest (Houghton \& Woodliff, 1987). For this purpose, two analyses were used: forward and backward stepwise. By using forward stepwise analysis one includes, step by step, those indicators which were characterized by highest discriminant ability. In contrast, using backward stepwise analysis at first, one takes into account all initial indicators in the model, and then, at each step, the one which has the least discriminant ability is eliminated from the model. Table 1 shows the values of the lambda Wilks coefficient for the individual variables included in the model.

The combination of five variables has provided the lowest level of the Wilks' Lambda index. In contrast, the highest coefficient level is a combination of two variables. The final model will be constructed based on five financial ratios drawn from the three areas of activity of companies: profitability (X19), turnover (X48, X62), and debt (X10, X16).

Fifth, assigning weights to individual indicators - after selecting the indicators included in the model, the next step was to determine the weights. The weights of indicators were estimated using the regression function and the form of the traditional discriminant model:

$$
S T=2,69953 X 19-0,00104 X 62-0,63553 X 48
$$$$
+2,18805 X 10+1,94727 X 16-1,30283
$$

where:

$$
\begin{aligned}
& X 19=\frac{\text { gross profit }}{\text { sales }} \\
& X 62=\frac{(\text { short-term liabilities } * 365)}{\text { sales }} ; \\
& X 48=\frac{\text { EBITDA }}{\text { total assets }} ; \\
& X 10=\frac{\text { equity }}{\text { total assets }} \\
& X 16=\frac{\text { (gross profit }+ \text { depreciation) }}{\text { total liabilities }} .
\end{aligned}
$$

Sixth, defining classes - cluster analysis was used to designate more than only two classes of financial condition of a company. For this purpose, the agglomeration method of cluster analysis was used by means of Statistica software. The result of this method is the tree of connections, the so-called dendrogram. Using this method the researcher subjectively determines the number of classes designating the tree cut-off line. A detailed information on the methods of cluster analysis can be found in: Bezdek (1981). In order to construct this tree of connections Ward's method and the Euclidean distance were used, which determine the cluster for selected financial indicators. The results of the cluster analysis are shown in Figure 1.

In methods of agglomeration of cluster analysis, the cut-off line is determined by where the distance of linkage between concentrations starts to recede. In this case, the distance of linkage between concentrations begins to do so at five. However, the cut-off line is not set at five due to the very large number of clusters at this level with simultaneous low number of companies in these clusters. The cutoff line has been set at twenty. The line cuts through four clusters with a similar number of companies included in a given concentration. The first concentration consists of companies with good financial condition. The second concentration is composed of companies characterized by sufficient financial condition. While firms with poor financial condition form the third concentration. The fourth concentration is made up of enterprises with very poor financial standing. For each cluster, the limit values were determined for the traditional discriminant model and the descriptive statistics were calculated for a Bayesian model.

Seventh, traditional discriminant model - for the obtained form of the discriminant model the limit values were established according to the specified number of clusters. Four concentrations were identified. On the basis of the analysis of the agglomeration it was necessary to check which companies were part of the cluster. Subsequently, the mean values of the function were calculated by using the traditional discriminant model (see formula 1). Function values for a given concentration are as follows:

- <-1.71 - companies with good financial condition

- $[-1.71 ;-0.51)$ - enterprises with sufficient financial condition

- $[-0.51 ; 1.05)$ - businesses with poor financial situation

- $[1.05 ; 2.34]$ - companies characterized by a very poor financial standing 
Table 1. Values of Wilks' lambda

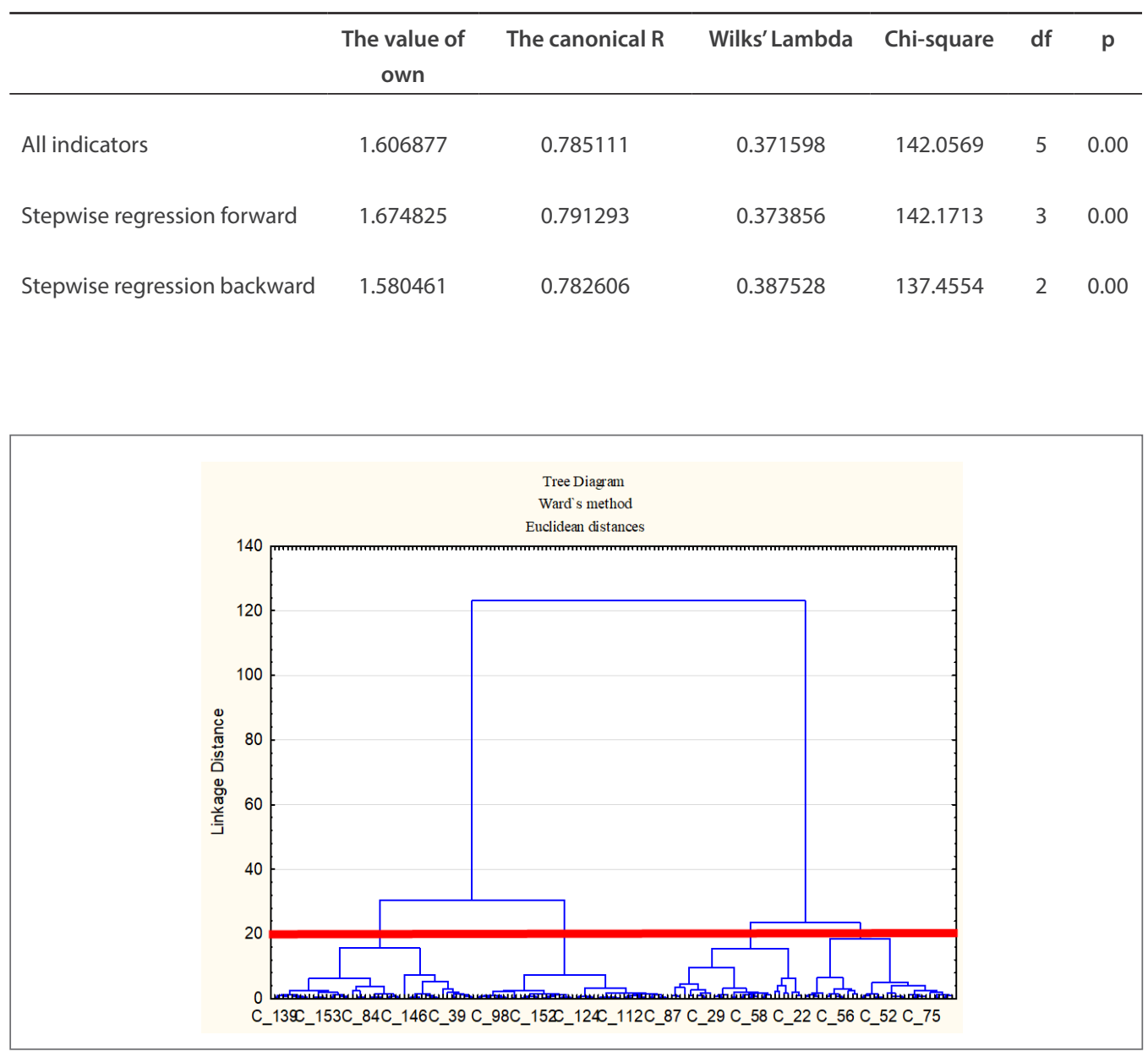

Figure 1. Cluster analysis - the learning sample.

- $>2.34$ - enterprises with critical financial condition

When a company obtains a value below -1.71 in the model, this means that the financial condition of the company is good, and when the model value is higher than 2.34 , it means that the financial health of the business is critical.

Eighth, Bayesian model - the selected financial ratios for construction of the traditional discriminant model were also used to construct a Bayesian model to enable the comparison and evaluation of these two models. The aim of the Bayesian model was the correct assignment of businesses to the defined classes. On the basis of the cluster analysis four classes, in other words concentrations, were defined. The probability was calculated a priori, based on the percentage of undertakings eliminated from the market in relation to the total number of operating ones. Therefore, a priori probability for Class 1 and 2 will be equal and it amounts to 0.465 and for Class 3 and 4 will also be equal and it amounts to 0.035 . Class 1 is a group of under- 
takings having good financial condition. Class 2 is a group of companies characterized by a sufficient financial situation. On the other hand, Class 3 is a group of companies described by poor financial standing, and Class 4 is a group of companies that has a very poor financial condition. The application of the model requires the calculation of descriptive statistics for each concentration (Table 2).

The descriptive statistics were calculated based on average values and the standard deviation of the financial indicators for the listed companies constituting a particular concentration. During the selection of financial indicators, the financial ratios have been tested by appropriate trials of whether or not values adopt the normal distribution. In addition, the descriptive statistics were calculated for the individual classes for each indicator, then the value of the conditional density function was determined as $f\left(x_{i} \mid z_{j}\right)$, where $i=1,2,3,4,5 ; z_{j}=1,2,3,4$.

Bayes algorithm assumes statistical independence. Thus, the total distribution of the probability density function is the product of density functions of conditional probability distributions of financial indicators in the specified classes:

$f\left(x \mid z_{j}\right)=f\left(x_{1} \mid z_{j}\right) * f\left(x_{2} \mid z_{j}\right) * f\left(x_{3} \mid z_{j}\right) * f\left(x_{4} \mid z_{j}\right) * f\left(x_{5} \mid z_{j}\right)$,

$z_{j}=1,2,3,4$

This relationship is represented by the following formula:

$f\left(x \mid z_{j}\right)=\prod_{i=1}^{5} \frac{1}{\sqrt{2 \pi \sigma_{i j}^{2}}} \exp \left[\frac{-\left(x_{i}-\overline{x_{i j}}\right)^{2}}{2 \pi \sigma_{i j}^{2}}\right]$

where:

$\sigma_{i j^{-}}$standard deviation of $\mathrm{i}$-feature of $\mathrm{j}$-class;

$\overline{\mathrm{x}}_{i j}$ - expected value of $\mathrm{i}$-feature of $\mathrm{j}$-class;

$\mathrm{X}_{i}$ - i-feature of classified object.

Assuming a priori probability and calculating of the overall probability density function allows the use of a Bayesian algorithm because it has full probabilistic information.

$$
P\left(z_{j} \mid x\right)=\frac{p\left(z_{j}\right) * f\left(x \mid z_{j}\right)}{\sum_{j=1}^{K} p\left(z_{j}\right) * f\left(x \mid z_{j}\right)}, \mathrm{j}=1,2,3,4
$$

where:

$P\left(z_{j} \mid x\right)$ - a posteriori probability of belonging to $\mathrm{j}$ class,

$p\left(z_{j}\right)$ - a priori probability of $\mathrm{j}$-class,

$p\left(x \mid z_{j}\right)$ - conditional density of characteristics of $\mathrm{j}$ class,

$\mathrm{K}$ - the number of classes.

The Bayesian algorithm includes the object to this class $j_{o}$, for which:

$p\left(z_{j o}\right) * f\left(x \mid z_{j o}\right)=\max _{j} p\left(z_{j}\right) * f\left(x \mid z_{j}\right), \mathrm{j}=1,2,3,4$

The following research questions were put forward in the article:

Does the verification of models based on validation sample significantly affect their accuracy?

Is the Bayesian model characterized by a higher correct classification of enterprises than the traditional discriminant model?

\section{Results}

In this section, the financial situation of manufacturing companies was assessed by the two constructed models: a traditional discriminant model and Bayesian model. These models were estimated based on a test sample of 224 companies and a validation sample - the analysis of accuracy type I of approximately 600 bankrupt companies and analysis of accuracy type II of more than 10,000 still operating companies.

\subsection{Traditional Discriminant Model}

The characteristics and the limit values of the discriminant traditional model were known, therefore the financial condition of manufacturing companies was examined on the basis of the test and validation sample (Table 3) and the validation of the samples (Tables 4 and 5). The upper part of Table 3 refers to bankrupt enterprises in the five years prior to bankruptcy. While the lower part of the table concerns companies still operating on the market in the same period as concerns the bankrupt enterprises.

Analyzing the results of the assessment of the financial condition of bankrupt enterprises, it can be said that the failed companies were mostly described 
Table 2. Descriptive Statistics for Each Cluster

\begin{tabular}{|c|c|c|c|c|c|c|}
\hline The number of clusters & The statistics & X19 & $\mathrm{X} 62$ & X48 & $\mathrm{X} 10$ & $\mathrm{X} 16$ \\
\hline \multirow[t]{5}{*}{ Cluster 1} & Average & 0.12 & 61.41 & 0.14 & 0.66 & 0.72 \\
\hline & Standard deviation & 0.06 & 23.84 & 0.11 & 0.11 & 0.33 \\
\hline & Min & 0,03 & 23,02 & 0,00 & 0,56 & 0,47 \\
\hline & Max & 0,29 & 102,46 & 0,68 & 0,85 & 1,81 \\
\hline & Median & 0,10 & 54,31 & 0,10 & 0,72 & 0,69 \\
\hline \multirow[t]{5}{*}{ Cluster 2} & Average & 0.05 & 75.29 & 0.02 & 0.59 & 0.25 \\
\hline & Standard deviation & 0.03 & 31.57 & 0.03 & 0.09 & 0.12 \\
\hline & Min & $-0,09$ & 24,84 & $-0,15$ & 0,44 & 0,03 \\
\hline & Max & 0,29 & 160,31 & 0,32 & 0,75 & 0,68 \\
\hline & Median & 0,06 & 69,50 & 0,04 & 0,58 & 0,3 \\
\hline \multirow[t]{5}{*}{ Cluster 3} & Average & -0.06 & 144.48 & -0.07 & 0.31 & -0.09 \\
\hline & Standard deviation & 0.08 & 60.62 & 0.11 & 0.22 & 0.17 \\
\hline & Min & $-0,23$ & 28,70 & $-0,34$ & $-0,02$ & $-0,51$ \\
\hline & Max & 0,04 & 263,64 & 0,11 & 0,87 & 0,19 \\
\hline & Median & $-0,01$ & 126,24 & $-0,03$ & 0,29 & $-0,02$ \\
\hline \multirow[t]{5}{*}{ Cluster 4} & Average & -0.20 & 286.26 & -0.17 & 0.05 & -0.21 \\
\hline & Standard deviation & 0.13 & 138.57 & 0.10 & 0.24 & 0.13 \\
\hline & Min & $-0,27$ & 87,19 & $-0,36$ & $-0,27$ & $-0,49$ \\
\hline & Max & $-0,03$ & 437,30 & 0,10 & 0,42 & 0,00 \\
\hline & & $-0,14$ & 212,77 & $-0,14$ & 0,17 & $-0,21$ \\
\hline
\end{tabular}


by a poor financial standing in the studied period of five years. As the bankruptcy was approaching, the financial situation of firms deteriorated - undertakings characterized by a critical financial condition increased. In contrast, every fourth company operating in the market was also characterized by poor financial standing. The remaining two thirds of companies were marked by sufficient or good financial standing. Next, the financial situation of the manufacturing companies was verified on the basis of validation of type I accuracy - approximately 600 bankrupt companies.

Analyzing the results of the study presented in the above Table 4, it can be concluded that in the period in question virtually $80 \%$ of companies were characterized by poor, very poor, or critical financial situation. The closer to declaring bankruptcy, the more firms with critical financial condition. Subsequently, the financial condition of companies was also verified on the basis of more than 10,000 companies still operated in the manufacturing sector (Table 5).

When analyzing the financial condition of enterprises operating in the sector, it should be noted that nearly half of the surveyed companies was characterized by poor financial standing. The poor financial condition does not automatically mean bankruptcy. Sometimes, some of the companies seem to be drifting in the market, staying in a vegetative state. The author has analyzed the values of models for companies with poor financial situation - the values are close to zero. For balanced and two-class system models, the separating point is assumed to be zero. This may mean that companies will be classified as enterprises that remain in the market in the next reporting period.

\subsection{Bayesian Model}

Having the full probabilistic picture, one can test the financial condition of companies by using a probabilistic model. The evaluation of the financial health of companies from the test and validation samples is presented in Tables 6, 7, and 8.

Analyzing the results presented in the above Table 6 , it is concluded that the bankrupt firms had a poor financial standing in the studied period of five years. As the bankruptcy approached, the financial condition of companies deteriorated - there was an increase in companies characterized by very poor financial standing. While the vast majority of companies operating on the market were described by good and sufficient financial condition. Next, the financial standing of enterprises was assessed based on validation of type I accuracy - approximately 600 bankrupt companies.

Analyzing the results shown in Table 7, it can be seen that in the period in question the closer business failure was, the higher the percentage of companies characterized by very poor financial standing turned out to be.

In assessing the financial situation of enterprises operating in the sector, it can be said that two thirds of companies were described by good and sufficient financial standing, whereas one fourth had poor financial condition.

The financial condition of manufacturing companies, that is to say the prospects for its evolution over time, can be evaluated using the models. Thus, the objective of the models is to inform businesses about existing and projected financial difficulties.

\subsection{The Analysis of the Results of the Classification of Enterprises}

Juxtaposing the two models, it should be noted that there are substantial differences in the way they are calculated. The Bayesian model classified a company based on the determined conditional probability that the selected firm belongs to a particular class. The article identifies four classes. The company will be assigned to the class for which a posteriori probability is the highest. However, in the traditional model a company is classified on the basis of the determined values of the model. This model cannot be used in determining the four clusters, because in the traditional model one determines some intervals outside which the company is classified. In this case there is one class more.

The traditional model evaluates the financial condition of failed enterprises better than the Bayesian model. It informed that nearly $80 \%$ of companies were characterized by poor or worse financial condition during the period of five years before bankruptcy. In contrast, the Bayesian model better assessed the financial situation of still operating enterprises on the market based on a test sample. It should be noted that there is a high percentage of companies characterized by poor financial standing. As mentioned above, the values for this class for the traditional model are virtually zero. This means that firms have financial standing at the 
Table 3. The Results of the Test Sample for the Traditional Model

\begin{tabular}{|c|c|c|c|c|c|}
\hline $\begin{array}{l}\text { Class of financial con- } \\
\text { dition of the bankrupt } \\
\text { companies }\end{array}$ & $\begin{array}{l}\text { five years } \\
\text { before bank- } \\
\text { ruptcy }\end{array}$ & $\begin{array}{c}\text { four years } \\
\text { before bank- } \\
\text { ruptcy }\end{array}$ & $\begin{array}{l}\text { three years } \\
\text { before bank- } \\
\text { ruptcy }\end{array}$ & $\begin{array}{l}\text { two years before } \\
\text { bankruptcy }\end{array}$ & $\begin{array}{c}\text { a year before } \\
\text { bankruptcy }\end{array}$ \\
\hline critical & $5.08 \%$ & $6.67 \%$ & $18.69 \%$ & $16.67 \%$ & $27.63 \%$ \\
\hline very poor & $15.25 \%$ & $10.67 \%$ & $16.82 \%$ & $19.61 \%$ & $21.05 \%$ \\
\hline poor & $52.54 \%$ & $56.00 \%$ & $46.73 \%$ & $42.16 \%$ & $32.89 \%$ \\
\hline sufficient & $11.86 \%$ & $13.33 \%$ & $8.41 \%$ & $9.80 \%$ & $5.26 \%$ \\
\hline good & $15.25 \%$ & $13.33 \%$ & $9.35 \%$ & $11.76 \%$ & $13.16 \%$ \\
\hline $\begin{array}{l}\text { Class of financial condi- } \\
\text { tion of operating com- } \\
\text { panies }\end{array}$ & $\begin{array}{l}\text { five years } \\
\text { before bank- } \\
\text { ruptcy }\end{array}$ & $\begin{array}{l}\text { four years } \\
\text { before bank- } \\
\text { ruptcy }\end{array}$ & $\begin{array}{l}\text { three years } \\
\text { before bank- } \\
\text { ruptcy }\end{array}$ & $\begin{array}{l}\text { two years before } \\
\text { bankruptcy }\end{array}$ & $\begin{array}{c}\text { a year before } \\
\text { bankruptcy }\end{array}$ \\
\hline critical & $0.00 \%$ & $1.05 \%$ & $0.00 \%$ & $0.00 \%$ & $0.00 \%$ \\
\hline very poor & $0.00 \%$ & $0.00 \%$ & $0.91 \%$ & $0.00 \%$ & $0.00 \%$ \\
\hline poor & $34.72 \%$ & $30.53 \%$ & $29.09 \%$ & $21.62 \%$ & $27.03 \%$ \\
\hline sufficient & $29.17 \%$ & $30.53 \%$ & $26.36 \%$ & $38.74 \%$ & $36.04 \%$ \\
\hline good & $36.11 \%$ & $37.89 \%$ & $43.64 \%$ & $39.64 \%$ & $36.94 \%$ \\
\hline
\end{tabular}

Table 4. The Test Results of Validation of the Traditional Model for the Bankrupt Enterprises

\begin{tabular}{|c|c|c|c|c|c|}
\hline $\begin{array}{l}\text { Class of financial condi- } \\
\text { tion }\end{array}$ & $\begin{array}{c}\text { five years } \\
\text { before bank- } \\
\text { ruptcy }\end{array}$ & $\begin{array}{l}\text { four years be- } \\
\text { fore bankruptcy }\end{array}$ & $\begin{array}{c}\text { three years } \\
\text { before bank- } \\
\text { ruptcy }\end{array}$ & $\begin{array}{l}\text { two years before } \\
\text { bankruptcy }\end{array}$ & $\begin{array}{l}\text { a year before } \\
\text { bankruptcy }\end{array}$ \\
\hline critical & $10.48 \%$ & $11.56 \%$ & $17.90 \%$ & $23.06 \%$ & $33.22 \%$ \\
\hline very poor & $16.59 \%$ & $19.38 \%$ & $21.23 \%$ & $20.63 \%$ & $21.17 \%$ \\
\hline poor & $48.91 \%$ & $47.81 \%$ & $47.06 \%$ & $39.56 \%$ & $30.62 \%$ \\
\hline sufficient & $12.23 \%$ & $11.25 \%$ & $6.91 \%$ & $8.50 \%$ & $6.84 \%$ \\
\hline good & $11.79 \%$ & $10.00 \%$ & $6.91 \%$ & $8.25 \%$ & $8.14 \%$ \\
\hline
\end{tabular}


Table 5. The Test Results of Validation of the Traditional Model for Companies Operating in the Sector.

\begin{tabular}{|c|c|c|c|c|c|c|c|c|c|c|}
\hline $\begin{array}{c}\text { Class of financial } \\
\text { condition }\end{array}$ & 2000 & 2001 & 2002 & 2003 & 2004 & 2005 & 2006 & 2007 & 2008 & 2009 \\
\hline critical & $5.5 \%$ & $5.7 \%$ & $5.3 \%$ & $4.0 \%$ & $2.6 \%$ & $2.0 \%$ & $1.7 \%$ & $1.5 \%$ & $4.8 \%$ & $5.1 \%$ \\
\hline very poor & $13.3 \%$ & $11.5 \%$ & $11.4 \%$ & $10.9 \%$ & $5.6 \%$ & $6.9 \%$ & $6.8 \%$ & $6.4 \%$ & $10.7 \%$ & $9.3 \%$ \\
\hline poor & $45.5 \%$ & $47.0 \%$ & $46.6 \%$ & $46.4 \%$ & $43.6 \%$ & $43.2 \%$ & $46.0 \%$ & $43.7 \%$ & $40.8 \%$ & $41.0 \%$ \\
\hline sufficient & $17.9 \%$ & $19.0 \%$ & $18.9 \%$ & $20.7 \%$ & $24.9 \%$ & $25.0 \%$ & $21.4 \%$ & $23.2 \%$ & $18.4 \%$ & $20.4 \%$ \\
\hline \multirow[t]{2}{*}{ good } & $17.8 \%$ & $16.7 \%$ & $17.8 \%$ & $18.0 \%$ & $23.3 \%$ & $22.8 \%$ & $24.1 \%$ & $25.2 \%$ & $25.3 \%$ & $24.2 \%$ \\
\hline & 2010 & 2011 & 2012 & & & & & & & \\
\hline critical & $5.5 \%$ & $3.3 \%$ & $8.0 \%$ & & & & & & & \\
\hline very poor & $8.4 \%$ & $8.0 \%$ & $11.8 \%$ & & & & & & & \\
\hline poor & $42.9 \%$ & $43.1 \%$ & $46.0 \%$ & & & & & & & \\
\hline sufficient & $20.5 \%$ & $21.1 \%$ & $17.0 \%$ & & & & & & & \\
\hline good & $22.7 \%$ & $24.4 \%$ & $17.2 \%$ & & & & & & & \\
\hline
\end{tabular}

border of the two classes: poor and sufficient. With a smaller number of classes, businesses can be assigned to companies that will continue to operate on the market in the next reporting time period.

\subsection{Comparison of the Results}

In the relevant literature, when it comes to verifying the models, the matrix method is used. It is a very simple method to identify the accuracy of type I and II of the models. The explanation of accuracy of type I and II was mentioned above. In this section, the traditional model and the Bayesian model were modified to assess the financial situation distinguishing two classes: Class 1: companies with good financial standing, and Class 2: companies with poor financial situation. The new descriptive statistics and a priori probability for the Bayesian model were calculated (Table 9).

This paper aims to state clearly which constructed model is characterized by higher accuracy. The number of classes that a model has enables other researchers to investigate the accuracy of the models, because two-class models can be easily assessed and compared with each other. Unlike other model verification researchers, the author verified the models based not only on a small sample but also on a large sample on the percentage of accuracy of the models. This allowed the author to compare samples with each other. In many studies, there is a huge decline in the correct recognition of companies by a model. In the author's opinion, the results on the large sample were more reliable.

Calculated a priori probability is based on the percentage of companies eliminated from the market in relation to the total number of operating firms. Therefore a priori probability for Class 1 is 0.93 and for Class 2 is 0.07 . In contrast, the new descriptive statistics 
Table 6. The Results of the Test Sample for the Bayesian Model

\begin{tabular}{|c|c|c|c|c|c|}
\hline $\begin{array}{l}\text { Class of financial con- } \\
\text { dition of the bankrupt } \\
\text { companies }\end{array}$ & $\begin{array}{l}\text { five years } \\
\text { before bank- } \\
\text { ruptcy }\end{array}$ & $\begin{array}{c}\text { four years } \\
\text { before bank- } \\
\text { ruptcy }\end{array}$ & $\begin{array}{l}\text { three years } \\
\text { before bank- } \\
\text { ruptcy }\end{array}$ & $\begin{array}{l}\text { two years before } \\
\text { bankruptcy }\end{array}$ & $\begin{array}{c}\text { a year before } \\
\text { bankruptcy }\end{array}$ \\
\hline very poor & $6.00 \%$ & $6.25 \%$ & $13.83 \%$ & $23.33 \%$ & $27.69 \%$ \\
\hline poor & $48.00 \%$ & $50.00 \%$ & $51.06 \%$ & $46.67 \%$ & $43.08 \%$ \\
\hline sufficient & $18.00 \%$ & $21.88 \%$ & $17.02 \%$ & $13.33 \%$ & $9.23 \%$ \\
\hline good & $28.00 \%$ & $21.88 \%$ & $18.09 \%$ & $16.67 \%$ & $20.00 \%$ \\
\hline $\begin{array}{l}\text { Class of financial condi- } \\
\text { tion of operating com- } \\
\text { panies }\end{array}$ & $\begin{array}{l}\text { five years } \\
\text { before bank- } \\
\text { ruptcy }\end{array}$ & $\begin{array}{l}\text { four years } \\
\text { before bank- } \\
\text { ruptcy }\end{array}$ & $\begin{array}{l}\text { three years } \\
\text { before bank- } \\
\text { ruptcy }\end{array}$ & $\begin{array}{l}\text { two years before } \\
\text { bankruptcy }\end{array}$ & $\begin{array}{c}\text { a year before } \\
\text { bankruptcy }\end{array}$ \\
\hline very poor & $1.56 \%$ & $0.00 \%$ & $0.00 \%$ & $0.00 \%$ & $0.00 \%$ \\
\hline poor & $4.69 \%$ & $3.61 \%$ & $3.06 \%$ & $4.08 \%$ & $2.02 \%$ \\
\hline sufficient & $34.38 \%$ & $36.14 \%$ & $32.65 \%$ & $33.67 \%$ & $43.43 \%$ \\
\hline good & $59.38 \%$ & $60.24 \%$ & $64.29 \%$ & $62.24 \%$ & $54.55 \%$ \\
\hline
\end{tabular}

Table 7. The Test Results of Validation of the Bayesian Model for the Bankrupt Enterprises

\begin{tabular}{|c|c|c|c|c|c|}
\hline $\begin{array}{l}\text { Class of financial condi- } \\
\text { tion }\end{array}$ & $\begin{array}{c}\text { five years } \\
\text { before bank- } \\
\text { ruptcy }\end{array}$ & $\begin{array}{l}\text { four years be- } \\
\text { fore bankruptcy }\end{array}$ & $\begin{array}{c}\text { three years } \\
\text { before bank- } \\
\text { ruptcy }\end{array}$ & $\begin{array}{l}\text { two years before } \\
\text { bankruptcy }\end{array}$ & $\begin{array}{l}\text { a year before } \\
\text { bankruptcy }\end{array}$ \\
\hline very poor & $12.16 \%$ & $14.33 \%$ & $20.05 \%$ & $26.08 \%$ & $34.13 \%$ \\
\hline poor & $41.44 \%$ & $46.18 \%$ & $46.35 \%$ & $42.28 \%$ & $38.91 \%$ \\
\hline sufficient & $23.42 \%$ & $20.06 \%$ & $19.79 \%$ & $17.22 \%$ & $11.60 \%$ \\
\hline good & $22.97 \%$ & $19.43 \%$ & $13.80 \%$ & $14.43 \%$ & $15.36 \%$ \\
\hline good & $11.79 \%$ & $10.00 \%$ & $6.91 \%$ & $8.25 \%$ & $8.14 \%$ \\
\hline
\end{tabular}


Table 8. The Test Results of Validation of the Bayesian Model for Companies Operating in the Sector

\begin{tabular}{|c|c|c|c|c|c|c|c|c|c|c|}
\hline $\begin{array}{l}\text { Class of financial } \\
\text { condition }\end{array}$ & 2000 & 2001 & 2002 & 2003 & 2004 & 2005 & 2006 & 2007 & 2008 & 2009 \\
\hline very poor & $9.4 \%$ & $9.9 \%$ & $8.9 \%$ & $7.3 \%$ & $4.9 \%$ & $4.3 \%$ & $3.4 \%$ & $3.4 \%$ & $7.3 \%$ & $7.9 \%$ \\
\hline poor & $31.9 \%$ & $31.6 \%$ & $29.7 \%$ & $28.3 \%$ & $21.0 \%$ & $22.3 \%$ & $23.5 \%$ & $23.0 \%$ & $26.9 \%$ & $25.6 \%$ \\
\hline sufficient & $26.4 \%$ & $27.5 \%$ & $29.6 \%$ & $31.4 \%$ & $31.2 \%$ & $33.8 \%$ & $31.9 \%$ & $29.5 \%$ & $25.6 \%$ & $27.5 \%$ \\
\hline \multirow[t]{2}{*}{ good } & $32.3 \%$ & $31.1 \%$ & $31.8 \%$ & $33.1 \%$ & $42.9 \%$ & $39.6 \%$ & $41.2 \%$ & $44.1 \%$ & $40.2 \%$ & $38.9 \%$ \\
\hline & 2010 & 2011 & 2012 & & & & & & & \\
\hline very poor & $7.7 \%$ & $5.0 \%$ & $8.6 \%$ & & & & & & & \\
\hline poor & $25.5 \%$ & $23.4 \%$ & $28.4 \%$ & & & & & & & \\
\hline sufficient & $31.0 \%$ & $33.5 \%$ & $32.2 \%$ & & & & & & & \\
\hline good & $35.8 \%$ & $38.1 \%$ & $30.9 \%$ & & & & & & & \\
\hline
\end{tabular}

Table 9. The Test Results of Validation of the Bayesian Model for Companies Operating in the Sector

\begin{tabular}{|c|c|c|c|c|c|c|c|}
\hline The number of clusters & A priori & The statistics & X19 & X62 & $\mathrm{X} 48$ & $\mathrm{X} 10$ & $\mathrm{X} 16$ \\
\hline \multirow[t]{2}{*}{ Class 1} & 0,93 & Average & 0.0911 & 66.2237 & 0.0872 & 0.6388 & 0.5522 \\
\hline & & Standard deviation & 0.0573 & 25.8778 & 0.1062 & 0.1063 & 0.3506 \\
\hline \multirow[t]{2}{*}{ Class 2} & 0.07 & Average & -0.0938 & 184.2544 & -0.0838 & 0.2540 & -0.0782 \\
\hline & & Standard deviation & 0.1297 & 121.9215 & 0.1338 & 0.2746 & 0.2208 \\
\hline
\end{tabular}

were calculated by means of the average value and the standard deviation of the financial ratios for listed bankrupt companies and the mean value and standard deviation of financial indicators for companies having good financial condition.

Modification of the traditional model also involves changing the number of defined classes, but the form of the traditional discriminant model is the same (1). In order to obtain comparable results, the number of classes is also 2. The separating limit value of enterprises classed good from those classed poor in the traditional model will be 0 . This value is typically the 
separating value for the models constructed on the basis of a balanced learning sample. A summary of the performance of the two models is presented in Table 10.

The traditional model was characterized by the highest efficiency on the learning sample of the model - $91 \%$ of correct classifications in the year before bankruptcy. The Bayesian model performed about one and a half percent worse. However, the analysis of the test sample showed that the Bayesian model better classified companies than the traditional one $-87 \%$ of correct classifications in the year before bankruptcy. This efficiency one, two, and five years before bankruptcy was slightly lower than in the learning sample of the model, but in three and four years before bankruptcy was higher. The traditional model performed slightly worse in classifying the businesses, but the performance, between the learning sample and test, decreased by more than $5 \%$ over the period. On the other hand, the analysis of validation sample showed that the percentage of correct classifications of companies for the traditional model was almost the same as in the test sample. This means that the total accuracy of the traditional discriminant model for one, two, and three years before the bankruptcy is almost $84 \%$. This result can be considered satisfactory. However, the results of the total accuracy for the Bayesian model were not so promising. Especially when it comes to accuracy of type II. The model classified only $67 \%$ of still operating companies in the sector as companies that should continue to operate during the next reporting year.

\section{Discussion}

The financial standing of businesses can be evaluated by many models. But only those models that foresee bankruptcy relatively far in advance are useful. The study shows that the presented models were characterized by sufficient predictive ability in the five years before the bankruptcy of an enterprise. The use of this models eliminates two weaknesses of existing models - the "zero-one" assessment of the financial condition of a business and the universalism of models. Moreover, models were verified on the basis of a large research sample in order to get a complete picture of the performance of models.

The accuracy of the traditional model was higher than the accuracy of the Bayesian model but only in the validation sample. Based on the test sample, which is considered a small sample, it could be stated that the Bayesian model was characterized by the highest accuracy and was more stable than the traditional model. However, the analysis of a large sample showed that the model recognized bankrupt companies at the same level as in the small sample, but recognition of companies still operating in the sector was much worse. The accuracy of the models was improved in comparison to figures obtained by Tomczak, Radosiński (2017). The highest percentage of correct recognition of financial situation of manufacturing companies was achieved by the Gajdka, Stos 2 model almost $69 \%$. The reason for the lower level of accuracy is that the coefficients in the models have remained unchanged. In turn, the results were not so good in comparison to the outcome of Altman, IwanowiczDrozdowska, Laitinen, Suvas (2017). In their research, they tested only Altman models with various modifications of it. The accuracy of Altman models oscillated around $90 \%$. The higher level of accuracy of the models is caused by the modifications of it. Seven from eight assessed models used logistic regression analysis and only one used multiple discriminant analysis. This one was assessed based on all data (manufacturing and non-manufacturing companies).

The author realizes that the developed models also have several downsides. The biggest drawback is failure to take into account indicators based on cash flows, non-financial indicators, and macroeconomic indicators, which may influence the accuracy of the models. Indicators based on cash flows were not analyzed due to the lack of access to data. However, the usefulness of these indicators was efficient in many studies, including in: Aziz, Emanuel, Lawson (1988), Gombola, Haskins, Ketz, Williams, (1987), and Mossman, Bell, Swartz, Turtle (1998).

The author is considering constructing a specific early warning system (Tomczak, 2014), which would aim to inform about the changes taking place both in the enterprise and in the market (constant search for impulses changing the conditions of the company (Majewski, 2012)). Such a system would not be dedicated only to companies but also to a wider audience (Kaczmarek, 2012). This system should consist of several models evaluating the financial condition of companies, because each 
model takes into account the various aspects of a company, which will make it possible to assess the company from a broader perspective, as well as reducing the possibility of making an erroneous classification of the analyzed companies. Moreover, the system should also contain non-financial indicators, such as qualitative and macroeconomic indicators to name a few (Betz et al.,2014). This will allow to assess changes in the market as well as to evaluate potential business partners.

Mączyńska in many of her publications outlines the need to create models of early warning signals in order to identify looming crises in an enterprise (Mączyńska, 2013). So far, models have been created based on several financial indicators. The authors of these models called them early warning systems (according to the author the model consists of several indicators (usually financial), while an early warning system may consist of individual models as well as additional indicators e.g. non-financial and macroeconomic). The off balance sheet ratios significantly enhance the efficiency of models for predicting bankruptcy (Becchetti \& Sierra, 2003).

Consequently, further research will be necessary to develop the early warning system. The use of this system for a company in the production sector will enable low-cost and fast monitoring of the company as a whole, thus helping to reduce the risk of doing business, and to reduce cooperation, with business partners who are characterized by low financial condition and may have future financial problems (trust and control (Martyniuk, 2012)). It is worth noting that the early warning system is used to predict the occurrence of financial difficulties of the company but not to predict bankruptcy (Platt \& Platt, 2002).

\section{Conclusions}

In this article, the author constructed two models to assess the financial condition of enterprises operating in the manufacturing sector. Using these models the company's financial condition can be evaluated on the basis of distinguishing four classes (clusters). The first class includes companies with good financial standing. The second class describes enterprises with sufficient financial condition. In contrast, the third class includes companies with poor financial situation. In the last class are businesses with very poor financial health (classes were determined using cluster analysis, Ward method).

This eliminates the drawback of existing models which is the "zero-one" assessment of the financial condition of a company and the universalism of models is the last disadvantage which will be minimized by the author's constructed model. The models were tested on small (224 companies) and large (nearly 11,000 companies) samples of research that eliminates the third drawback being insufficient verification of the effectiveness of the models. The overall accuracy of constructed models is a satisfactory level. The models can serve as a tool to help to evaluate the financial health of companies, which can contribute to making the right decision.

Based on the conducted research, it can be said that the traditional discriminant model classified companies better than the Bayesian one. Verification of models on a large sample had a significant impact on their accuracy. The accuracy of the traditional model for the test and validation sample was almost at the same level - nearly $84 \%$ of correct recognition of companies for one, two, and three years before bankruptcy. However, the accuracy of the Bayesian model for the validation sample had decreased, particularly in the assessment of type II accuracy. It is worth mentioning that the type II error was less expensive than the type I error, especially for banks, because it involves only the loss of the benefits that the bank would receive if the company repaid a loan, for example loss of interest on the loan.

It should be pointed out that there are some differences in the way the models are calculated. The Bayesian model classifies a business on the basis of the determined conditional probability that the chosen enterprise belongs to a particular class. This means that the company will be assigned to the class for which a posteriori probability is the highest. In turn, the discriminant model classifies a business based on the determined values of the model. Thus, the company will be assigned to one of the determined values of intervals on the basis of the values of the model. In the case of the discriminant model, there is one interval more because there is no possibility to assign a company to the exact class based on probability but based on the value of the model to one of the values of intervals. 
Table 10. The Accuracy of the Two Models.

\begin{tabular}{|c|c|c|c|c|c|c|}
\hline Sample & \multicolumn{2}{|c|}{$\begin{array}{l}\text { Learning sample } \\
\qquad 200\end{array}$} & \multicolumn{2}{|c|}{$\begin{array}{c}\text { Test sample } \\
224 \\
\end{array}$} & \multicolumn{2}{|c|}{$\begin{array}{c}\text { Validation sample accuracy I } \\
600 ; \text { accuracy } 1110,000\end{array}$} \\
\hline \multirow[t]{2}{*}{ Model } & \multicolumn{2}{|c|}{ Total accuracy } & \multicolumn{2}{|c|}{ Total accuracy } & \multicolumn{2}{|c|}{ Total accuracy } \\
\hline & type I & type II & type I & type II & type I & type $\mathrm{II}^{\star}$ \\
\hline \multirow{2}{*}{$\begin{array}{l}\text { Discriminant model - } \\
\text { a year before bankruptcy }\end{array}$} & \multicolumn{2}{|c|}{$91.5 \%$} & \multicolumn{2}{|c|}{$84 \%$} & \multicolumn{2}{|c|}{$83.7 \%$} \\
\hline & $88 \%$ & $95 \%$ & $80 \%$ & $88 \%$ & $80.5 \%$ & $86.9 \%$ \\
\hline \multirow[t]{2}{*}{2 years before bankruptcy } & \multicolumn{2}{|c|}{$89.0 \%$} & \multicolumn{2}{|c|}{$81 \%$} & \multicolumn{2}{|c|}{$81.6 \%$} \\
\hline & $82 \%$ & $96 \%$ & $72 \%$ & $90 \%$ & $76.2 \%$ & $86.9 \%$ \\
\hline \multirow[t]{2}{*}{3 years before bankruptcy } & \multicolumn{2}{|c|}{$86.0 \%$} & \multicolumn{2}{|c|}{$84 \%$} & \multicolumn{2}{|c|}{$83.4 \%$} \\
\hline & $78 \%$ & $94 \%$ & $78 \%$ & $90 \%$ & $79.8 \%$ & $86.9 \%$ \\
\hline \multirow[t]{2}{*}{4 years before bankruptcy } & \multicolumn{2}{|c|}{$79.0 \%$} & \multicolumn{2}{|c|}{$76.5 \%$} & \multicolumn{2}{|c|}{$79.7 \%$} \\
\hline & $71 \%$ & $87 \%$ & $70 \%$ & $83 \%$ & $72.5 \%$ & $86.9 \%$ \\
\hline \multirow[t]{2}{*}{5 years before bankruptcy } & \multicolumn{2}{|c|}{$80.0 \%$} & \multicolumn{2}{|c|}{$74.0 \%$} & \multicolumn{2}{|c|}{$77.3 \%$} \\
\hline & $79 \%$ & $81 \%$ & $67 \%$ & $81 \%$ & $67.7 \%$ & $86.9 \%$ \\
\hline \multirow{2}{*}{$\begin{array}{l}\text { Bayesian model - } \\
\text { a year before bankruptcy }\end{array}$} & \multicolumn{2}{|c|}{$90.0 \%$} & \multicolumn{2}{|c|}{$87 \%$} & \multicolumn{2}{|c|}{$71.2 \%$} \\
\hline & $82 \%$ & $98 \%$ & $77 \%$ & $97 \%$ & $76.5 \%$ & $67.0 \%$ \\
\hline \multirow[t]{2}{*}{2 years before bankruptcy } & \multicolumn{2}{|c|}{$86.0 \%$} & & & & \\
\hline & $73 \%$ & $99 \%$ & $73 \%$ & $95 \%$ & $70.9 \%$ & $67.0 \%$ \\
\hline 3 years before bankruptcy & & & & & & \\
\hline & $66 \%$ & $96 \%$ & $68 \%$ & $98 \%$ & $68.8 \%$ & $67.0 \%$ \\
\hline 4 years before bankruptcy & & & & & & \\
\hline & $58 \%$ & $96 \%$ & $62 \%$ & $96 \%$ & $63.2 \%$ & $67.0 \%$ \\
\hline 5 years before bankruptcy & & & & & & \\
\hline & $66 \%$ & $84 \%$ & $58 \%$ & $86 \%$ & $58.4 \%$ & $67.0 \%$ \\
\hline Note: ${ }^{*}-$ means that this is th & se of acc & f type II & years ( & $2012)$ & & \\
\hline
\end{tabular}


Furthermore, these models are easy to use, to assess and compare with each other. However, they are sensitive to the data, especially for outliers. In order to eliminate this issue, in future research, the decision tree learning methods will be tested, e.i. boosted trees trained with Extreme Gradient Boosting as well as the Author will investigate the possibility of utilizing off-balance sheet data in early warning models for assessing the financial standing of a company. Moreover, perspective study will also include deep learning modelling performed on a much bigger sample size of the selected group.

\section{References}

Altman, E. (1968). Financial ratios, discriminant analysis and the prediction of corporate bankruptcy. Journal of Finance, 23(4), 589-609.

Altman, E. (1993). Corporate financial distress and bankruptcy (2nd ed.). John Wiley \& Sons.

Altman, E.I., \& Saunders, A. (1998). Credit risk measurement: Developments over the last 20 years. Journal of Banking \& Finance, 21(11-12), 17211742 .

Altman, E.I., \& Hotchkiss, E. (2006). Corporate financial distress and bankruptcy (3rd ed.). John Wiley \& Sons.

Altman, E.I., Iwanowicz-Drozdowska, M., Laitinen, E.K., \& Suvas, A. (2017). Financial Distress Prediction in an International Context: A Review and Empirical Analysis of Altman's Z-Score Model, Journal of International Financial Management \& Accounting, 28(2), 131-171.

Appenzeller, D., \& Szarzec, K. (2004). ), Prognozowanie zagrożenia upadłością polskich spółek publicznych [Forecasting the risk of bankruptcy of Polish public companies]. Rynek Terminowy, 1, 120-128.

Aziz, A., Emanuel, D. C., \& Lawson, G. H. (1988). Bankruptcy prediction - an investigation of cash flow based models. Journal of Management Studies, 25(5), 419-437.

Beaver, W. H. (1966). Financial ratios as predictors of failure. Journal of Accounting Research, 5, 71-111.

Becchetti, L., \& Sierra, J. (2003). Bankruptcy risk and productive efficiency in manufacturing firms. Journal of Banking \& Finance, 27(11), 2099-2120.

Bellovary, J. L., Giacomino, D. E., \& Akers, M. D. (2007). A review of bankruptcy prediction studies: 1930 to present. Journal of Financial Education, 33, Winter, 1-42.
Betz, F., Oprica, S., Peltonen, T. A., \& Sarlin, P. (2014). Predicting distress in European banks. Journal of Banking \& Finance, 45, 225-241.

Bezdek, J. C. (1981). Pattern Recognition with Fuzzy Objective Function Algorithms. Plenum Press.

Cheung L., \& Levy A. (1998). An integrative analysis of business bankruptcy in Australia. Journal of Economics and Finance, 22(2-3), 149-167.

Gajdka, J., \& Stos, D. (1996a). Wykorzystanie analizy dyskryminacyjnej do badania przydatności przedsiębiorstwa na bankructwo [The use of discriminant analysis to examine the suitability of a company for bankruptcy]. In J. Duraj (Ed.), Company on the Capital Market (pp. 138-148), Wydawnictwo Uniwersytetu Łódzkiego

Gajdka, J., \& Stos, D. (1996b). Wykorzystanie analizy dyskryminacyjnej $w$ ocenie kondycji finansowej przedsiębiorstw [The use of discriminant analysis in the assessment of the financial condition of enterprises]. In R. Borowiecki (Ed.), Restructuring in the Process of Transformation and Development of Enterprises (pp. 138-148).Wydawnictwo Akademii Ekonomicznej w Krakowie

Gajdka, J., \& Stos, D. (2003). Ocena kondycji finansowej polskich spólek publicznych w okresie 1998-2001 [Assessment of the financial condition of Polish public companies in the period 1998-2001]. In D. Zarzecki (Ed.), Time for Money, Financial Management. Measuring Results and Business Valuations (pp. 150-162). Wydawnictwo Uniwersytetu Szczecińskiego.

Gombola, M. J., Haskins, M.E., Ketz, J. E., \& Williams, D.D. (1987). Cash flow in bankruptcy prediction. Financial Management, 16(4), 55-65.

Grice, J.S., \& Ingram, R. W. (2001). Tests of the generalizability of Altman's bankruptcy prediction model. Journal of Business Research, 54(1), 53- 61.

Hamrol, M., Czajka, B., \& Piechocki, M. (2004). Upadłość przedsiębiorstwa - model analizy dyskryminacyjnej [The bankruptcy of a company - discriminant model]. Organization Review, 6, 34-38.

Hołda, A. (2001). Prognozowanie bankructwa jednostki w warunkach gospodarki polskiej z wykorzystaniem funkcji dyskryminacyjnej Zh [Prediction of the bankruptcy of a company in the Polish economy using a discriminant function. $Z h$ ]. Rachunkowość, 5, 306-310.

Houghton, K. A., \& Woodliff, D. R. (1987). Financial ratios: The prediction of corporate 'success' and failure. Journal of Business Finance \& Accounting, 14(4), 537-554. 
Jackson, R.H.G., \& Wood, A. (2013). The performance of insolvency prediction and credit risk models in the UK: A comparative study. The British Accounting Review, 45, 183-202.

Juszczyk, S., \& Balina, R. (2014). Prognozowanie zagrożenia bankructwem przedsiębiorstw $w$ wybranych branzach [Predicting the threat of bankruptcy to enterprises of some selected branches]. Economist, 1, 67-96.

Kaczmarek, J. (2012). Construction elements of bankruptcy prediction models in multi-dimensional early warning systems. Polish Journal of Management Studies, 5, 136-149.

Kisielińska J. (2016). The effectiveness of corporate bankruptcy models. Economic and Regional Studies, 9(1), 5-17.

Majewska, J., Zdanowicz, B. (2006). System oceny i prognozowania zagrożeń oraz monitorowania sytuacji finansowej banków (omówienie dyskusji) [The system for assessing and forecasting threats and monitoring the financial standing of banks (the discussion)]. Safe Bank, 2(31), 88-93.

Majewski, B. (2012). Systemy wczesnego ostrzegania $\mathrm{w}$ zarządzaniu [Early warning systems in management]. Studia $i$ prace Kolegium Zarzadzania $i$ Finansów, 118, 96-103.

Martyniuk, O. (2012). Ryzyko w przedsiębiorstwie i sposoby jego ograniczania [The risk in the company and ways to limit it]. Rachunkowość, 2, 7-15.

Mączyńska, E. (1994). Ocena kondycji przedsiębiorstwa [Assessment of a company's condition], Życie Gospodarcze, 38, 42-43.

Mączyńska, E., \& Zawadzki, M. (2006). Dyskryminacyjne modele predykcji bankructwa przedsiębiorstw [Models of discriminant analysis in the prediction of corporate insolvency]. Economist, 2, 205-234.

Mączyńska, E. (2013). Modele wczesnego ostrzegania przed bankructwem i zagrozenia w!działalności gospodarczej jako narzędzie wspomagania analiz finansowych [Early bankruptcy warning systems as a tool to support financial analyses]. Retrieved from www.pte.pl (in Polish).

Mossman, C.E., Bell, G.G., Swartz, L.M., \& Turtle, H. (1998). An empirical comparison of bankruptcy models. The Financial Review, 33(2), 35-54.

Platt, H. D., \& Platt, M. B. (2002). Predicting corporate financial distress: Reflections on choice-based sample bias. Journal of Economics and Finance, 26 (2), 184-198.

Prusak, B. (2005). Nowoczesne metody prognozowania zagrożenia finansowego przedsiębiorstw
[Modern Methods for Predicting the Financial Threat to Companies]. Difin.

Reisz, A. S., \& Perlich, C. (2007). A market-based framework for bankruptcy prediction. Journal of Financial Stability, 3(2), 85-131.

Springate, G. L. V. (1978). Predicting the Possibility of Failure in a Canadian Firm. Unpublished M.B.A. Research Project, Canada, Simon Fraser University.

Taffler, R. J. (1983). The assessment of company solvency and performance using a statistical model. Accounting and Business Research, 15(52), 295-308.

Tomczak, S. K. (2014). The early warning system. Journal of Management and Financial Sciences, 7(16), 51-74.

Tomczak, S. K., Radosiński, E. (2017). The effectiveness of discriminant models based on the example of the manufacturing sector. Operations Research and Decisions, 3, 81-97.

Wu, Y., Gaunt, C., Gray, S. (2010). A comparison of alternative bankruptcy prediction models. Journal of Contemporary Accounting and Economics, 6(1), $34-45$. 